\title{
Work engagement among participants of residency and professional development programs in nursing
}

\author{
Engagement no trabalho entre residentes e aprimorandos de enfermagem
}

Engagement en el trabajo entre residentes y profesionales en perfeccionamiento de enfermería

Luciano Garcia Lourenção'
'Universidade Federal do Rio Grande, School of Nursing. Rio Grande, Rio Grande do Sul, Brazil.
How to cite this article:
Lourenção LG. Work engagement among participants of residency and professional development programs in nursing.
$\begin{gathered}\text { Rev Bras Enferm [Internet]. 2018;71(Suppl 4):1487-92. [Thematic Issue: Education } \\ \text { and teaching in Nursing] DOI: http://dx.doi.org/10.1590/0034-7167-2017-0278 }\end{gathered}$

Submission: 05-04-2017 Approval: 07-16-2017

\section{ABSTRACT}

Objective: to assess the levels of engagement at work of nurses enrolled in multi-professional residency and professional development programs in health care of a Brazilian public institution. Method: a cross-sectional study with 36 professionals. The data were collected in September 2013, with use of the Utrecht Work Engagement Scale (UWES), composed of seventeen self-evaluation items with the dimensions vigor, dedication and absorption, as well as an overall score. Results: the levels of engagement ranged from 3.8 to 4.3, and the standard deviations, between 1.1 and 1.3. Nurses showed average levels on vigor (3.8) and absorption (3.9) dimensions, and high levels on dedication $(4,3)$ and engagement (4.0). Conclusion: the professionals presented good levels of energy, resilience, enthusiasm and involvement with the work. They are satisfied with the activity and are dedicated to it, which promotes the acquisition of skills and competences along the in-service training, ensuring a future professional practice of quality.

Descriptors: Staff Development; Internship and Residency; Nursing Human Resources; Nursing; Education in Nursing.

\section{RESUMO}

Objetivo: Avaliar os níveis de engagement no trabalho de enfermeiros matriculados em programas de residência multiprofissional e aprimoramento profissional em saúde de uma instituição pública brasileira. Método: Estudo transversal com 36 profissionais. Os dados foram coletados em setembro de 2013, com o Utrech Work Engagement Scale (UWES), composto por dezessete itens de auto avaliação com as dimensões: vigor, dedicação e absorção, além de um escore geral. Resultados: os índices de engagement variaram de 3,8 a 4,3, e os desvios-padrão, entre 1,1 e 1,3. Os enfermeiros apresentaram níveis médios de vigor (3,8) e absorção (3,9), e níveis altos de dedicação $(4,3)$ e engagement $(4,0)$. Conclusão: Os profissionais apresentam bons níveis de energia, resiliência, entusiasmo e envolvimento com trabalho. Encontram-se satisfeitos e se identificam com o trabalho, o que favorece a aquisição de habilidades e competências ao longo da formação em serviço, assegurando uma prática profissional futura de qualidade.

Descritores: Desenvolvimento de Pessoal; Internato e Residência; Recursos Humanos de Enfermagem; Enfermagem; Educação em Enfermagem.

\section{RESUMEN}

Objetivo: evaluar los niveles de engagement en el trabajo de enfermeros matriculados en programas de residencia multiprofesional y perfeccionamiento profesional en salud de una institución pública brasileña. Método: estudio transversal con 36 profesionales. Los datos fueron recogidos en septiembre del 2013, mediante la Utrech Work Engagement Scale (UWES), compuesta por diecisiete ítems de autoevaluación con las dimensiones vigor, dedicación y absorción, además de una puntuación general. Resultados: los índices de engagement variaron de 3,8 a 4,3, y los desvíos estándar, entre 1,1 y 1,3. Los enfermeros presentaron niveles medios de vigor $(3,8)$ y absorción $(3,9)$, y niveles altos de dedicación $(4,3)$ y engagement $(4,0)$. Conclusión: los profesionales presentan buenos niveles de energía, resiliencia, entusiasmo e involucración con el trabajo. Se encuentran satisfechos con la actividad y se dedican a ella, lo que favorece a adquisición de habilidades y competencias a lo largo de la formación en servicio, lo que asegura una práctica profesional futura de calidad. Descriptores: Desarrollo de Personal; Internado y Residencia; Recursos Humanos de Enfermería; Enfermería; Educación en Enfermería. 


\section{INTRODUCTION}

Linked to positive psychology, engagement is a recent concept that draws the interest of researchers due to the positive effect caused on performance, health and well-being of profession$\mathrm{als}^{(1)}$. The concept involves a process of positively using the workplace, which makes the professionals more satisfied with the profession, demonstrating greater well-being and intentions of staying at the workplace, and that is characterized by three dimensions: vigor, dedication and absorption ${ }^{(2-3)}$.

Literature points that engagement is a shield from burnout ${ }^{(4-5)}$, and may interfere with the quality of the service provided to users of the health system due to the positive relationship of professionals with their workplace, generating consequences such as: increased productivity, greater enthusiasm, interaction with colleagues, motivation, creativity, reduced absenteeism and fewer errors ${ }^{(2-3,6-8)}$.

Studies with workers enrolled in in-service training programs, such as multidisciplinary residency and professional development in health care, indicate that the presence of factors such as work overload, attending critical patients, frequent contact with pain and suffering, living with the uncertainties and limitations of technical knowledge and of the assistance system may compromise the performance ${ }^{(7,9)}$.

However, the proposal for professional qualification through in-service training under supervision, which is inherent to these programs, is believed to promote the development of attitudes and professional skills that ensure a safe and quality service, meeting the demands of the users of the public health system ${ }^{(9-12)}$.

Residency and professional development programs are consolidated in nursing as an important area of qualification, allowing the exchange of knowledge between the various specialties and between the scientific and the popular knowledge, since the professionals are inserted into the health services integrating theory and practice, in contact with users and communities ${ }^{(9,12-13)}$.

Thus, measuring engagement allows the levels of motivation and professional fulfillment of nurses in continuous training process to be verified, contributing to reflections on the working conditions and on the psychosocial impact on workers, on organization and on the users of health services.

\section{OBJECTIVE}

To evaluate levels of engagement at work of nurses enrolled in multi-professional residency and professional development programs in health care of a Brazilian public institution.

\section{METHOD}

\section{Ethical aspects}

The study received a favorable opinion from the Research Ethics Committee of Faculdade de Medicina of São José do Rio Preto. The ethical principles of voluntary and consented participation of each subject were respected.

\section{Study design, location and period}

Cross-sectional study performed among nurses enrolled in multi-professional residency and professional development programs in health care of an educational institution located in the interior of the state of São Paulo (SP), Brazil, in 2013.

\section{Population or sample, inclusion and exclusion criteria}

The population of the study consisted of nurses enrolled in multi-professional residency and professional development programs in health care that consented to participate in the study after being informed on its objectives and purposes, with a total of 36 professionals. These programs are educational arrangements characterized by in-service training under full-time supervision, with workload of 60 and 40 hours per week ${ }^{(10-11)}$, respectively, distributed in theoretical $(20 \%)$ and practical $(80 \%)$ activities, as determined by the legislation ${ }^{(10,14-15)}$.

The professionals who were clear of their activities for any reason during the period of data collection were excluded.

\section{Study protocol}

Data collection was performed with use of two self-report instruments: one elaborated by the authors, containing variables to define the profile of professionals, such as age, sex, marital status, weekly workload, practice of physical activity, leisure activity, family income, if they are satisfied or if they ever think about quitting the program; and the Brazilian Version of the Utrecht Work Engagement Scale (UWES), validated in Brazil by Vasquez et al. ${ }^{(16)}$, composed by seventeen self-evaluation items with three dimensions, vigor, dedication and absorption, as well as an overall score ${ }^{(2)}$.

Vigor refers to high levels of energy and resilience, the will to invest efforts, not fatiguing easily and persisting when facing difficulties. Those that present high scores of vigor usually have a lot of energy when working, unlike those with low scores on this dimension ${ }^{(2,6-7)}$.

Dedication is related to a sense of meaning of the work, the feeling of excitement and pride in labor, which inspires and challenges. Professionals with high scores in dedication identify strongly with their work because the experience is meaningful, inspiring and challenging. In addition, they usually feel excited and proud about their job. Those that present low scores do not identify themselves with the job because they do not experience it as meaningful, inspiring or challenging, and feel no excitement or pride ${ }^{(2,-6-7)}$.

Absorption refers to be fully immersed in the work and finding it difficult to let go of it; time passes quickly, and the professional forgets everything around. Presenting high absorption rates implies feeling involved and focused during work. Consequently, everything around is forgotten and time seems to fly ${ }^{(2,6-7)}$.

The data were collected in September 2013 at the start of a theoretical class, after at least six months of professional activities on the programs. After the permission of the teacher in charge, the questionnaires were applied by the researcher and a trained collaborator to all nurses enrolled in the programs that were not away at the time.

\section{Results analysis and statistics}

The sociodemographic data were used to characterize the population of the study. For analysis of the engagement, the scores were calculated according to the statistical model 
proposed in the UWES Preliminary Manual ${ }^{(2)}$, presenting the values of minimum, maximum, median, mean $( \pm$ standard deviation) and $95 \%$ confidence interval for each dimension of the UWES. The values obtained were interpreted with use of the UWES Preliminary Manual as shown in Table 1.

Table 1 - Model for interpretation of the mean values of the study

\begin{tabular}{|c|c|}
\hline Classification & $\begin{array}{l}\text { Frequency of feelings in relation to work } \\
\text { (UWES questions) }\end{array}$ \\
\hline Very Low & $\begin{aligned} \text { From } 0 \text { to } 0.99 & =0 \text { (never) } \\
& =1 \text { (at least once a year) }\end{aligned}$ \\
\hline Low & From 1 to $1.99=2$ (at least once a month) \\
\hline \multirow{2}{*}{ Average } & From 2 to $2.99=3$ (at least a couple of times a month) \\
\hline & From 3 to $3.99=4$ (at least once a week) \\
\hline High & From 4 to $4.99=5$ (at least a few times a week) \\
\hline Very high & From 5 to $6=6$ (daily) \\
\hline
\end{tabular}

Note: Utrecht Work Engagement Scale (UWES)

Data were analyzed with use of the Statistical Package for Social Sciences (SPSS) software, version 17.0.

The comparisons were made with use of the Chi-square test, considering significant p-value less than or equal to 0.05 .

\section{RESULTS}

36 nurses participated in the study, with women prevalence (94.4\%). The age of professionals ranged from 22 to 35 years, with an average of 25.5 years (SD: \pm 2.7 years) and C195\% of 24.6 to 26.5 years; single $(86.1 \%)$, with household income of two to five minimum wages $(58.3 \%)$; most professionals participated in the Professional Development Program and worked 40 hours a week (58.3\%), did not practice physical activity $(61.1 \%)$ and reported leisure activity $(52.8 \%)$. We highlight that $69.4 \%$ of the professionals reported being satisfied with the residency program, the same percentage of nurses who considered quitting the program (69.4\%) (Table 2).

Table 3 presents the results of the evaluation of the levels of work engagement from the distribution of the coefficients of reliability, minimum, maximum, median, mean $( \pm$ standard deviation) and 95\% confidence interval, according to the dimensions of the UWES: vigor, dedication, absorption and engagement. On the analysis of reliability, the Cronbach's alpha values ranged from 0.805 to 0.945 . The mean of dimensions ranged from 3.8 to 4.3 and the standard deviations, between 1.1 and 1.3. Vigor and absorption dimensions obtained average levels, and dedication and engagement dimensions, high levels.

The levels of work engagement, according to weekly workload, reported satisfaction and desire to quit the programs, are presented in Table 4.
Table 2 - Distribution of sociodemographic characteristics of nurses enrolled in the multi-professional residency and professional development programs in health care

\begin{tabular}{|c|c|c|c|}
\hline & & $\mathbf{n}$ & $\%$ \\
\hline \multirow[t]{2}{*}{ Sex } & Man & 02 & 5.6 \\
\hline & Women & 34 & 94.4 \\
\hline \multirow[t]{3}{*}{ Age group } & $20-25$ years & 21 & 58.3 \\
\hline & $26-30$ years & 13 & 36.1 \\
\hline & $31-35$ years & 02 & 5.6 \\
\hline \multirow[t]{2}{*}{ Marital status } & Married & 05 & 13.9 \\
\hline & Single & 31 & 86.1 \\
\hline \multirow{4}{*}{$\begin{array}{l}\text { Household income } \\
\text { (minimum wages) }^{*}\end{array}$} & Up to 1 & 01 & 2.8 \\
\hline & From 2 to 5 & 21 & 58.3 \\
\hline & From 6 to 10 & 12 & 33.3 \\
\hline & More than 10 & 02 & 5.6 \\
\hline \multirow[t]{2}{*}{ Practice of sports } & Yes & 14 & 38.9 \\
\hline & No & 22 & 61.1 \\
\hline \multirow[t]{3}{*}{ Leisure activity } & Yes & 19 & 52.8 \\
\hline & No & 15 & 41.7 \\
\hline & Did not answer & 02 & 5.6 \\
\hline \multirow[t]{2}{*}{ Weekly Workload } & 40 hours $^{* *}$ & 21 & 58.3 \\
\hline & 60 hours $^{* * *}$ & 15 & 41.7 \\
\hline \multirow[t]{2}{*}{ Satisfied with the program } & Yes & 25 & 69.4 \\
\hline & No & 11 & 30.6 \\
\hline \multirow[t]{2}{*}{ Thought about quitting the program } & Yes & 25 & 69.4 \\
\hline & No & 11 & 30.6 \\
\hline
\end{tabular}

Note: "Value of the minimum wage: 744.00 BRL. ${ }^{* *}$ Professional Development Program. ${ }^{* * *}$ Multi-professional Residency Program.

Regarding workload, the professionals showed average levels on the absorption dimension, regardless of the weekly workload. For the dedication dimension, the professionals working 40 hours a week showed average levels; among those working 60 hours a week, the levels were high. For all other dimensions, all professionals showed high levels.

Professionals who declared themselves satisfied with the programs for all dimensions of the UWES presented the highest engagement values.

Table 3 - Distribution of the coefficients of reliability, minimum, maximum, median, mean ( \pm standard deviation) and 95\% confidence interval for the dimensions of the Utrechtt Work Engagement Scale (UWES), according to the assessment of nurses enrolled in the multi-professional residency and professional development in health care programs

\begin{tabular}{cccccccc}
\hline $\begin{array}{c}\text { UWES } \\
\text { Dimensions }\end{array}$ & Cronbach's alpha & Min Max & Md & Mean \pm SD & CI (95\%) & Interpretation \\
\hline Vigor & 0.901 & 0.3 & 5.3 & 4.0 & $3.8 \pm 1.3$ & $3.4-4.2$ & Average \\
Dedication & 0.911 & 0.4 & 6.0 & 4.6 & $4.3 \pm 1.3$ & $3.8-4.7$ & High \\
Absorption & 0.805 & 1.0 & 5.7 & 4.2 & $3.9 \pm 1.1$ & $3.5-4.3$ & Average \\
Engagement & 0.945 & 0.6 & 5.5 & 4.2 & $4.0 \pm 1.1$ & $3.6-4.4$ & High \\
\hline
\end{tabular}

Note: Min: minimum; Max: maximum; Md: median; SD: standard deviation; 95\% Cl: 95\% confidence interval; UWES -Utrecht Work Engagement Scale. 
Table 4 - Distribution of means ( \pm standard deviation) for the scales of the Utrechtt Work Engagement Scale (UWES), according to weekly workload, reported satisfaction and desire to quit the programs

\begin{tabular}{|c|c|c|c|c|c|c|c|c|c|c|c|c|}
\hline & \multicolumn{3}{|c|}{ Vigor } & \multicolumn{3}{|c|}{ Dedication } & \multicolumn{3}{|c|}{ Absorption } & \multicolumn{3}{|c|}{ Engagement } \\
\hline & $\begin{array}{c}\text { Mean } \\
\pm \text { SD }\end{array}$ & Interpretation & $\begin{array}{c}p \\
\text { value }\end{array}$ & $\begin{array}{c}\text { Mean } \\
\pm S D\end{array}$ & Interpretation & $\begin{array}{c}p \\
\text { value }\end{array}$ & $\begin{array}{c}\text { Mean } \\
\pm \text { SD }\end{array}$ & Interpretation & $\begin{array}{c}p \\
\text { value }\end{array}$ & $\begin{array}{c}\text { Mean } \\
\pm \text { SD }\end{array}$ & Interpretation & $\begin{array}{c}p \\
\text { value }\end{array}$ \\
\hline \multicolumn{13}{|c|}{ Weekly Workload } \\
\hline 40 hours $^{* *}$ & $4.4 \pm 1.2$ & High & 0.808 & $3.8 \pm 1.2$ & Average & 0.756 & $3.8 \pm 1.3$ & Average & 0.632 & $4.0 \pm 1.1$ & High & 0.586 \\
\hline 60 hours $^{* * *}$ & $4.1 \pm 1.5$ & High & & $4.0 \pm 1.1$ & High & & $3.8 \pm 1.3$ & Average & & $4.0 \pm 1.2$ & High & \\
\hline \multicolumn{13}{|c|}{ Satisfaction with the Program } \\
\hline Yes & $4.2 \pm 1.1$ & High & 0.156 & $4.6 \pm 1.3$ & High & 0.075 & $4.1 \pm 1.1$ & Alto & 0.087 & $4.3 \pm 1.1$ & High & 0.392 \\
\hline No & $3.0 \pm 1.2$ & Average & & $3.5 \pm 1.2$ & Average & & $3.4 \pm 1.1$ & Average & & $3.3 \pm 0.9$ & Average & \\
\hline \multicolumn{13}{|c|}{ Thought about quitting the program } \\
\hline Yes & $3.4 \pm 1.3$ & Average & 0.118 & $3.8 \pm 1.3$ & Average & 0.284 & $3.6 \pm 1.1$ & Average & 0.361 & $3.6 \pm 1.1$ & Average & 0.210 \\
\hline No & $4.8 \pm 0.5$ & High & & $5.3 \pm 0.5$ & Very high & & $4.7 \pm 0.6$ & Average & & $4.9 \pm 0.5$ & High & \\
\hline
\end{tabular}

Note: ${ }^{* *}$ Professional Development Program. ${ }^{* * *}$ Multi-professional Residency Program.

The professionals who thought about quitting the programs showed average levels in all dimensions of the UWES, while those who never thought of quitting presented average levels on the absorption dimension, high on engagement and vigor, and very high on dedication.

\section{DISCUSSION}

The results of this study show that the nurses in the process of in-service professional training present high levels of engagement on all dimensions, especially on dedication. Brazilian studies with medical residents of Pedriatics ${ }^{(17)}$ and with professionals on development programs ${ }^{(18)}$ found similar results, showing that the professionals have good levels of engagement.

Levels of engagement on a research on readiness and commitment of nurses to changes in hospitals were lower than the levels identified on the nurses of this study. According to the author, the level of engagement interferes with the commitment of the professional to perform activities that contribute to patient safety, such as proper hand washing ${ }^{(19)}$.

These results show that the studied nurses are satisfied and identify with the work, which promotes the acquisition of skills and competences throughout in-service training, ensuring a future professional practice of quality.

The professionals who declared themselves satisfied or did not think of quitting the programs showed higher levels of engagement in relation to those dissatisfied or, who thought of quitting the residency/development at some point. Despite the inherent difficulties of the in-service training process pointed by literature, no significant statistical difference in levels of engagement between the groups, evidencing the involvement of these professionals with the work $^{(9,13,20-23)}$.

The engagement levels found among the professionals in this research are supported by a Portuguese study with nurses in hospital units, it presented medium and high levels of engagement, varying between regions, hospitals and assistance units ${ }^{(24)}$.

Havens et al. ${ }^{(25)}$, claims that the engagement of nurses is influenced by the professional practice environment. Thus, while there is no specific set of factors for the development of engagement ${ }^{26)}$, implementing of measures such as the identification and valuing of preferences, personal and professional goals and values of nurses; the direct and constant supervision; the monitoring of the development of activities and the achievement of the goals set, with constant reviews, can strengthen the involvement of medical residents, promoting engagement within the institution.

Working environments that provide social support are important to obtain high levels of engagement reported by the professionals ${ }^{(25)}$. Similarly, satisfactory levels of dedication among the workers will depend on the support provided by managers ${ }^{(27)}$.

Cardoso $^{(27)}$ analyzed the importance of social support to promote engagement of Portuguese nurses and showed that the support of colleagues influences the level of engagement of the nurses directly and positively, especially in the dimensions of vigor and dedication, while the support provided by the managers interferes with the dedication of the professional. However, the author points that this is only possible if there is no excess of work, since this overload damages the relation between social support and engagement.

Given this context, the evaluation of the working conditions by the coordinators, teachers and tutors of the residency and professional development programs in nursing is fundamental, avoiding overload and providing social support to stimulate the development of engagement and that the working environment is conducive to the training and performance of these professionals.

\section{Study limitations}

The main limitation of the study was the lack of publications on the topic, emphasizing the need for more scientific research on engagement among participants of residency and professional improvement programs in nursing. New studies, with professionals from different institutions, inserted in other contexts of in-service professional training, could make this assessment more effective, as well as the understanding of the factors that interfere on the level of professional engagement, in its different dimensions (force, absorption, dedication). Another limitation was performing the study on a single training center, restricting the analysis of results. 


\section{Contributions to the nursing field and public health}

This study contributes to the reflection of the relation between participants of residency and professional development programs and the working environment where they perform their professional training, contributing to the understanding of the impact of cultural and organizational differences, experiences and types of assistance in developing the engagement of these professionals, improving the process of in-service training proposed by the residency and professional development programs.

Furthermore, by contributing to the reflection of the relation of professionals with their working environment, this study may encourage the implementation of adjustments and improvements that favor in-service training, providing the insertion of better trained professionals to care for users of health services, especially of the Brazilian Unified Health System (SUS).

\section{CONCLUSION}

The results of this study showed that nurses have good levels of engagement in all dimensions evaluated, showing good levels of energy and resilience, enthusiasm and involvement with the work. They declared satisfaction with the activity and are dedicated to it, which promotes the acquisition of skills and competences throughout the in-service training, ensuring a future professional practice of quality. This evidences that the engagement is a good indicator of well-being, for both the residents and the institutions in which they are inserted.

This study highlights the importance of assessing the motivation and satisfaction of professionals in in-service training programs, reflecting on their working conditions. Thus, reinforcing the view that the occupational health of nurses interferes with their individual performance, influencing the quality of the service offered to the population.

\section{FUNDING}

Faculdade de Medicina de São José do Rio Preto, Program of Research Scholarships (Programa de Bolsas de Pesquisa de Assistência à Pesquisa) 2013/2014.

\section{REFERENCES}

1. Bakker A. An evidence-based model of work engagement. Curr Dir Psychol Sci [Internet]. 2011[cited 2016 Jul 15];20(4):265-69. Available from: http://journals.sagepub.com/doi/abs/10.1177/0963721411414534

2. Agnst R, Benevides-Pereira AMT, Porto-Martins PC. Utrecht Work Engagement Scale. Schaufeli WB, Bakker AB, (Trad.). Curitiba: GEPEB; 2009.

3. Garcia SAP. Engagement no trabalho dos profissionais das Unidades de Cuidados de Saúde Primários e a sua relação com a performance e a satisfação no trabalho[Dissertação][Internet]. Lisboa: ISCTE; 2012. [cited 2016 Jul 14]. Available from: http://hdl. handle.net/10071/6288

4. Pereira AM, Pinto TV, Queirós C. Burnout e engagement em médicos e enfermeiros de unidades de saúde [Internet]. In: $10_{-}^{\circ}$ Congresso Nacional de Psicologia da Saúde. Porto, 6 a 8 de fevereiro de 2014[cited 2016 Jul 15]. Available from: https://repositorio-aberto. up.pt/bitstream/10216/71508/2/91693.pdf

5. Andrade PCC. Promoção do Savoring em Equipas de Enfermagem: aumento do engagement e prevenção do burnout[Dissertação] [Internet]. Porto: Instituto de Ciências Biomédicas Abel Salazar (ICBAS), 2012[cited 2016 Jul 14]. Available from: http://hdl.handle. net/10216/57196

6. Porto-Martins PC, Basso-Machado PG, Benevides-Pereira AMT. Engagement no trabalho: uma discussão teórica. Fractal Rev Psicol [Internet]. 2013[cited 2016 Jul 14];25(3):629-44. Available from: http://www.scielo.br/pdf/fractal/v25n3/a13v25n3.pdf

7. Salanova M, Schaufeli WB. El engagement en el trabajo. Madrid: Alianza; 2009.

8. Bakker AB, Albrecht SL, Leiter MP. Key questions regarding work engagement. Eur J Work Organ Psycol[Internet]. 2011 [cited 2016 Jul 14];20(1):4-28. Available from: http://psycnet.apa.org/record/2011-03226-003

9. Rotta DS, Pinto MH, Lourenção LG, Teixeira PR, Gonsalez EG, Gazetta CE. Anxiety and depression levels among multidisciplinary health residents. Rev Rene[Internet]. 2016[cited 2016 Jul 14];17(3):372-7. Available from: http://www.scielo.br/pdf/rbem/v41n4/01005502-rbem-41-04-0557.pdf

10. São Paulo. Secretaria de Estado da Saúde. Fundação do Desenvolvimento Administrativo-FUNDAP. Programa de Aprimoramento Profissional-PAP. Manual de Orientações Técnicas e Administrativas [Internet]. São Paulo. 2015 [cited 2016 Jul 14]. Available from: http://pap.fundap.sp.gov.br/arquivos/manual_pap2015.pdf

11. Brasil. Presidência da República. Lei $n^{\circ} 12.514$, de 28 de outubro de 2011. Dispõe sobre as atividades do médico-residente e trata das contribuições devidas aos conselhos profissionais em geral[Internet]. 2011 [cited 2016 Jul 14]. Available from: http://www. planalto.gov.br/ccivil_03/_Ato2011-2014/2011/Lei/L12514.htm\#art1

12. Miranda Neto MV, Leonello VM, Oliveira MAC. Residências multiprofissionais em saúde: análise documental de projetos político-pedagógicos. Rev Bras Enferm[Internet]. 2015[cited 2016 Jul 14];68(4):586-93. Available from: www.scielo.br/pdf/reben/ v68n4/0034-7167-reben-68-04-0586.pdf

13. Franco GP, Barros ALBL, Nogueira-Martins LA, Zeitoun SS. Burnout in nursing residents. Rev Esc Enferm USP [Internet]. 2011[cited 
2016 Jul 14];45(1):12-8. Available from: http://www.scielo.br/pdf/reeusp/v45n1/en_02.pdf

14. Brasil. Ministério da Saúde. Secretaria de Gestão do Trabalho e da Educação na Saúde. Departamento de Gestão da Educação na Saúde. Residência multiprofissional em saúde: experiências, avanços e desafios. Brasília; 2006.

15. Faculdade de Medicina de São José do Rio Preto. Comissão de Aprimoramento e Aperfeiçoamento da Funfarme e Famerp. Processo Seletivo 2016 [Internet]. São José do Rio Preto: Fac Medicina; 2015 [cited 2016 Jul 14]. Available from: http://www.famerp.br/ novoportal/index.php/processo-seletivo-coaprimo\#.Vo_hYPkrLDc

16. Vazquez ACS, Magnan ES, Pacico JC, Hutz CS, Schaufeli WB. Adaptation and Validation of the Brazilian Version of the Utrecht Work Engagement Scale. Psicol USF[Internet]. 2015[cited 2016 Jul 14];20(2):207-17. Available from: http://www.scielo.br/pdf/ pusf/v20n2/1413-8271-pusf-20-02-00207.pdf

17. Teixeira PR, Lourenção LG, Gazetta CE, Gonsalez EG, Rotta DS, Pinto MH, et al. Engagement no trabalho em residentes médicos de pediatria. Rev Bras Educ Med[Internet]. 2017[cited 2017 Jul 14];41(1):126-33. Available from: http://www.cadernosdeterapiaocupacional. ufscar.br/index.php/cadernos/article/view/1734

18. Gonsalez EG, Lourenção LG, Teixeira PR, Rotta DS, Gazetta CE, Beretta D, et al. Engagement no trabalho em profissionais de programas de aprimoramento profissional em saúde. Cad Ter Ocup UFSCar[Internet]. 2017[cited 2017 Jul 14];25(2):509-17. Available from: http://www.cadernosdeterapiaocupacional.ufscar.br/index.php/cadernos/article/view/1734

19. Jacinto SML. Prontidão para a mudança em enfermeiros no contexto hospitalar: associação com job engagement e perceção de autoeficácia[Dissertação] [Internet]. Lisboa: Universidade Lusófona de Humanidades e Tecnologias; 2014 [cited 2016 Jul 15]. Available from: http://hdl.handle.net/10437/5325

20. Carvalho CN, Melo-Filho DA, Carvalho JAG, Amorim ACG. Prevalência e fatores associados aos transtornos mentais comuns em residentes médicos e da área multiprofissional. J Bras Psiquiatr[Internet]. 2013[cited 2016 Jul 14];62(1):38-45. Available from: http://www.scielo.br/pdf/jbpsiq/v62n1/06.pdf

21. Lourenção LG, Moscardini AC, Soler ZASG. Quality life of residents non-doctors. J Nurs UFPE [Internet]. 2013 [cited 2016 Jul 14];7(11):6336-45. Available from: http://dx.doi.org/10.5205/reuol.3794-32322-1-ED.0711201304

22. West CP, Shanafelt TD, Kolars JC. Quality of life, burnout, educational debt, and medical knowledge among internal medicine residents. JAMA[Internet]. 2011[cited 2016 Jul 14];306(9):952-60. Available from: https://jamanetwork.com/journals/jama/fullarticle/1104293

23. Lourenção LG, Moscardini AC, Soler ZASG. Health and quality of life of medical residents. Rev Assoc Med Bras[Internet]. 2010[cited 2016 Jul 14];56(1):81-90. Available from: http://www.scielo.br/pdf/ramb/v56n1/en 21.pdf

24. Pinto AM, Jesus EH, Mendes AMOC, Fronteira ISE. Estudo RN4Cast em Portugal: work engagement dos enfermeiros. Rev Invest Enferm[Internet]. 2015[cited 2016 Jul 14];10(2):26-37. Available from: http://repositorio.esenfc.pt/?url=YJAzznEfa

25. Havens DS, Warshawsky NE, Vasey J. RN work engagement in generational cohorts: the view from rural US hospitals. J Nurs Manag[Internet]. 2013[cited 2016 Jul 14];21(7):927-40. Available from: https://www.ncbi.nlm.nih.gov/pubmed/24131081

26. Schaufeli WB, Salanova M. Enhancing work engagement through the management of human resources. In: Näswall, MSK, Hellgren J, (Eds.). The individual in the changing working life[Internet]. Cambridge: Cambrigde University Press; 2010 [cited 2016 Jul 15]. pgs. 380-404. Available from: http://www.fss.uu.nl/sop/Schaufeli/293.pdf

27. Cardoso T. Engagement nos enfermeiros: o papel do suporte social no bem-estar dos enfermeiros. [Dissertação] [Internet]. Lisboa: Faculdade de Psicologia e de Ciências da Educação; 2008[cited 2016 Jul 15]. Available from: http://hdl.handle.net/10451/748 